Uluslararası Sosyal ve Eğitim Bilimleri Dergisi
International Journal of Social and Educational Sciences
Cilt 7, Sayı 13, Haziran 2020 \& Vol 7, No 13, June 2020
e-ISSN 2148-8673

\title{
Ortaöğretim 11. Sınıf Biyoloji Ders Kitabında Sorumluluk Değerinin İncelenmesi
}

Investigation of Responsibility Value in 11th Grade Biology Textbook

\section{Esra Özay Köse* \& Şeyda Gül**}

\section{Öz}

Bireylerin, yaşadıkları çevreye ayak uydurabilmesi, toplum nazarında değerli bir insan olarak kabul edilmesi ve saygınlık kazanmasında sorumluluk duygusu önemli bir görev üstlenmiştir ki öğrencilerde sorumluluk duygusunun kazandırılması, eğitimin de önemli hedeflerindendir. Alan yazında birçok sorumluluk türü karşımıza çıkmakla beraber en sık yer alan sorumluluk türleri bireysel, sosyal ve çevresel sorumluluktur. Müfredatta yer alan kazanımların öğrencilere verilmesinde kullanılan en yaygın ve genel eğitim araçlarından biri de hiç şüphesiz ders kitaplarıdır. Buradan hareketle bu çalışmanın amacı biyoloji 11. sınıf ders kitaplarında sorumluluk değerine yer verilme durumunun belirlenmesidir. Araştırmada nitel araştırma yöntemlerinden doküman incelemesi kullanılmıştır. Çalışmanın veri kaynağını MEB tarafından kabul edilen ve 2018-2019 eğitim-öğretim yılına ait 11. sınıf biyoloji ders kitabı oluşturmaktadır. Verilerin analizinde betimsel analiz yapılmıştır. Kitapta yer alan tüm metinler (ders anlatımları, etkinlikler, okuma parçaları) cümle cümle incelemeye alınmış, her bir cümle içindeki, değerlere karşılık gelen sözcükler, belirtilen değerleri açıklayan ifadeler ya da doğrudan veya örtük anlamı veren cümleler alınmıştır. Elde edilen verilere göre 11. sınıf biyoloji ders kitabında sorumluluk değerine yer verilmekle birlikte en çok bireysel sorumluluk irdelenmiştir. Sosyal ve çevresel sorumluluk ise bireysel sorumluluktan sonra yer almıştır. Sonuç olarak sorumluluk değerinin kazandırılmasında biyoloji ders kitabında yer alan metinlerin de burada önemli bir rol oynadığı görülmektedir. Bu nedenle ders kitaplarında yer alan metinler, öğrencilere değerlerin öğretilmesinde için etkili araçlar arasında yer almaktadır. Dolayısıyla ders kitaplarında kullanılan metinlerin öğrencilere değer kazandıracak, onlara doğru davranışları sunacak bir içerikle verilmesi gerekmektedir.

Anahtar Kelimeler: biyoloji, ders kitabı, değerler eğitimi, sorumluluk değeri

\begin{abstract}
Responsibility has an important role for individuals to keep up with the environment they live in, to be accepted as a valuable person in the society and to gain respectability. Although there are many types of responsibility in the literature, the most common types of responsibility are individual, social and environmental responsibility. One of the most common and general tools used to give students the gains in the curriculum is undoubtedly textbooks. The aim of this study is to determine the status of responsibility in the 11th grade textbooks of biology. In the research, document analysis, one of the qualitative research methods, was used. The data source of the study consists of 11 th grade biology textbook which is accepted by the Ministry of National Education and belongs to 2018-2019 academic year. Descriptive analysis was used for data analysis. All the texts (lectures, activities and reading passages) in the book were analyzed sentence sentence and the words corresponding to the values, expressions explaining the specified values or sentences giving direct or implicit meaning were taken in each sentence. According to the data obtained, although the responsibility value is included in the 11th grade biology textbook, most of the individual responsibility is examined. Social and environmental responsibility followed the individual responsibility. As a result, we see that the texts in the biology textbook play an important role in gaining responsibility values. Therefore, the texts in the textbooks are among the effective tools for teaching values to students. Therefore, the texts used in the textbooks should be given with a content that will give value to the students and offer them the right behaviors.
\end{abstract}

Keywords: biology, textbook, values education, responsibility value

*(Prof. Dr.); Atatürk Üniversitesi, Eğitim Fakültesi, esraozay@ atauni.edu.tr, ORCID: orcid.org/0000-0001-9085-7478

** (Doç. Dr.); Atatürk Üniversitesi, Eğitim Fakültesi, seydagul@ atauni.edu.tr, ORCID: orcid.org/0000-0002-4005-2158

Kaynak Gösterme: Köse, E. Ö.; Gül, Ş. (2020). Ortaöğretim 11. Sınıf Biyoloji Ders Kitabında Sorumluluk Değerinin İncelenmesi. Uluslararası Sosyal ve Eğitim Bilimleri Dergisi, 7 (13), 1 - 15. DOI: 10.20860/ijoses.634150 


\section{Extended Summary}

\section{Purpose and Significance:}

Although there are many values determined by the Ministry of National Education in achieving values education, one of these values is "responsibility" value. The responsibility of individuals to adapt to the environment in which they live, to be regarded as a valuable person in the society and to gain respectability has an important role to play, and to gain the sense of responsibility among students is one of the important goals of education. ). Individual responsibility is the desire to set goals in life and to assume all responsibilities to achieve this goal. So one blames himself and not others for failing to achieve his goals. Individual responsibility is considered in two ways as the responsibility of the individual to his / her self and the responsibility of the person to his / her own body. The concept of social responsibility is used to describe the individual's responsibility towards other people. Other people's well-being includes well-being, well-being, a sense of inner duty to help others, civic involvement, and responsible behavior towards others. Environmental responsibility can be defined as activities such as using natural resources at sustainability level, performing all kinds of activities in a way that does not disturb the balance in the natural environment, taking precautions against possible problems such as environmental pollution and complying with national and international environmental standards. One of the most common and general tools used to give students the gains in the curriculum is undoubtedly textbooks. Studies conducted within the framework of textbooks in recent years show that textbooks are very effective in bringing values to society and spreading them. When this situation is taken into consideration, it is important to examine how the textbooks present in this regard. In addition, the fact that most of the studies conducted in the literature are aimed at primary education does not show the importance of values education for secondary school students. The aim of this study is to determine the status of responsibility in the 11th grade textbooks of biology.

\section{Methodology:}

In the research, document analysis, one of the qualitative research methods, was used. The data source of this study is 11th grade biology textbook of Kök Publishing which is distributed free of charge to secondary schools in 2018-2019 academic year. In the book, there are 2 separate units and the texts in the first part 7 and the second part of the second unit were examined and the responsibility value mentioned in these sections was determined. Descriptive analysis was used for data analysis. For descriptive analysis, the value of responsibility in the book was sought by reading the sentence by sentence. In each sentence, the words corresponding to the values, expressions explaining the specified values or sentences giving direct or implicit meaning were taken.

\section{Results, discussion and conclusion:}

According to the data obtained, although the responsibility value is included in the 11th grade biology textbook, the most responsibility responsibility is examined. Social and responsibility responsibility, responsibility awareness As a result of the analysis, the value of responsibility found in the two units of the book found in the texts. The first unit is human physiology technology. In these sections, organ structures, functioning, diseases and protection ways of the systems in the human body are mentioned in general. Naturally, human body structure, encounter system and ways of protection are mentioned. "Urinary system" and "reproductive system" sections emphasized the required responsibility value. 
However, in these chapters, you can only learn about the "What should we look out for your relevant information ve and health / illness". In addition, "circulatory system", "respiratory system" and "urinary system" The second unit describes Community and Population Ecology. The sections of this unit describe the structure of the community and the population, the coexistence of living things, and the content of the human population. Naturally, the human population has an environmental responsibility.

The fact that the responsibility value is included in the 11th grade textbooks of biology may also be due to the nature of the biology course. Because biology as a living science, nature and is a course that provides responsibility to living things. Biology course teaches to be sensitive to living things in the environment and develops their ability to help. In this course, the student realizes that today's youth has an important responsibility towards the environment and other living things as well as individual responsibility in terms of biological problems as adults of tomorrow and health issues related to their own body. With biology lesson, they awaken the interest and love of the student and learn the responsible behavior towards the other species that they share the nature when they are younger. In this respect, the biology course aims to be respectful to other creatures and individuals. As a result, it is noticed that the importance of responsibility value has diminished in recent years when technology and social media engage the society, especially students. We see that the texts in the biology textbook play an important role in gaining responsibility value. Therefore, the texts in the textbooks are among the effective tools for teaching value to students. Therefore, the texts used in the textbooks should be given with a content that will give value to the students and offer them the right behaviors. At this point, it can be suggested that especially biology textbooks and other science textbooks at other levels of secondary education should be examined in terms of values and studies on increasing the effectiveness of textbooks in value education can be suggested. 


\section{Giriş}

Öğrencilerin sosyal yaşama hazırlanmasında ve onlar için önemli olan ahlaki duyarlılıkların temelinin, sevginin, saygının, güvenin, sorumluluğun ve daha birçok değerin öğretilmesinde en önemli görevlerden biri eğitim kurumlarına düşmektedir. Öğrenciler bu değerleri tek başlarına düzgün olarak anlamlandıramayacağından, kazandırılması istenilen bu değerlerin doğru olarak anlamlandırılmasında okulların rolü büyüktür. Okullar öğrencileri sadece bilişsel hedefler çerçevesinde yetiştirmez. Bunun yanında duyuşsal ve psikomotor becerileri de kazandırma rolünü üstlenmiştir. Duyuşsal becerilerin kazanılması ise değerler eğitimi yoluyla olmaktadır. Değerler eğitimi kazanımları, öğretimin her kademesinde doğrudan veya ders konuları içerisinde örtük olarak verilmektedir (Akbaş, 2004). Gençler/çocuklar etraflarında cereyan eden çeșitli sorunlardan, șiddet gösterilerinden ve uygunsuz tavırlardan yoğun olarak etkilenmektedir. Eğitimciler sosyal düzeni etkileyen bu problemlerden sıyrılmanın çaresinin düzgün bir değerler eğitiminden geçtiği görüşündedirler (Tillman, 2000).

Değerler eğitimi kazanımlarında milli eğitim bakanlığının belirlemiş olduğu birçok değer olmakla birlikte bu değerlerden biri de "sorumluluk" değeridir. Bireylerin, yaşadıkları çevreye ayak uydurabilmesi, toplum nazarında değerli bir insan olarak kabul edilmesi ve saygınlık kazanmasında sorumluluk duygusu önemli bir görev üstlenmiştir ki öğrencilerde sorumluluk duygusunun kazandırılması, eğitimin de önemli hedeflerindendir (MEB, 2006).

Yavuzer (2000) sorumluluğu "çocukluk dönemlerinden başlayarak çocuğun yaşına, cinsiyetine ve gelişim düzeyine uygun olarak görevlerini yerine getirmesi” şeklinde açıklamıştır. Cüceloğlu (1996)' na göre sorumluluk; "kişinin sınırları içerisinde gördügü olaylardan ve şeylerden hesap vermeye hazır olması" olarak tanımlanmıştır. Eğitim öğretim ortamında ki rehberlik açısından ise sorumluluk, diğer insanların haklarına saygılı olmak ve kendi davranışlarının sonuçlarını üstlenmek şeklinde açıklanmıştır (Gündüz, 2014). Diğer taraftan Tucker (1999) sorumluluğu, öğrencilerin ebeveynlerinden, okulundan, arkadaş çevresinden ve yaşadığı çevreden öğrendiği bir değerdir şeklinde tanımlarken, Yontal ve Yurtal (2009) ise "öğrencilerin hayat boyu başarılı olmalarına katkı sağlayan bir yaşam hüneridir" biçiminde tanımlamıştır. Sorumluluk çeşitleri sorumluluğun değişik kaynaklardan temel alması sebebiyle her kuramcı, sorumluluğun farklı bir yönünü ele almaktadır. Bunlar da sorumluluk kavramına farklı içerik ve nitelikler kazandırmakta, farklı sınıflamalarla sorumluluk türlerini ortaya çıkarmaktadır. Bu sorumluluk tanımları incelendiğinde, sorumluluk için bazen kişisel özelliğinden yola çıkarak "bireysel sorumluluk" kavramı vurgulanırken, bazen de "sosyal sorumluluk" kavramı irdelenerek sorumluluğun hem bireysel hem de toplumsal boyutlar taşıdığını görmekteyiz. Zaten alan yazında sorumluluk bireysel ve sosyal sorumluluk diye iki şekilde ele alınmıştır (Özen, 2013). Bunun yanında çevreye duyarlılık öğrencilere kazandırılması düşünülen değerler arasında bulunmaktadır. Buna bağlı olarak çevreyle ilişkilendirebileceğimiz değerler ise sorumluluk ve merhamettir (Komisyon, 2010, s. 20-21). Buradan hareketle çevresel sorumluluk kavramı da ortaya çıkmaktadır.

Bireysel Sorumluluk; "kendi sorumluluğunu üstlenebilmek, kendinden sorumlu olmak, başardığında diğerlerini değil, sadece kendini kutlamak ve başaramadığında ise sadece kendini suçlamaktır." (Golzar, 2006). Bireysel sorumluluk hayatta hedef belirleme ve bu hedefe erişmek için tüm sorumlulukları yüklenme arzusudur. Böylece kişi hedeflerini gerçekleştirmedeki başarısızlıklarından ötürü başkalarını değil, bizzat kendini suçlar. Bireysel sorumluluk, bireyin kendi benliğine yönelik sorumluluğu ve kişinin kendi bedenine yönelik sorumluluğu diye iki şekilde ele alınmaktadır (Hamilton \& Fenzel, 1988).

Sosyal sorumluluk kavramı, bireyin diğer kişilere karşı sorumluluğunu anlatmak için kullanılmaktadır. Diğer insanların iyiliği, refahı, iyi olmalarıyla ilgili olma, başkalarına yardım etmeyi içeren içsel görev duygusu, sivil katılım ve başkalarına karşı sorumlu davranışları içermektedir (Özen, 2015). Berkowitz (1963) sosyal sorumluluğu söyle tanımlar; "sosyal sorumluluk bir kimsenin üzerine aldığ ya da yapmak zorunda olduğu bir iş için gerektiğinde hesap verme duygusudur." 
Çevresel sorumluluk doğal kaynakların sürdürülebilirlik düzeyinde kullanılması, her türlü etkinliklerin doğal çevrede dengeyi bozmayacak biçimde yapılması, çevre kirliliği gibi ortaya çıkabilecek problemlere karşı önlemler alınması, ulusal ve uluslararası çevre standartlarına uyulması gibi etkinlikler olarak tanımlanabilir (Can, 2013).

Türkiye'de son yıllarda değerler eğitimi açısından sorumluluğun ele alındığı çalışmalar giderek artmaktadır. Ancak yapılan çalışmaların çoğunlukla ilköğretim ve ortaöğretim programlarındaki sorumluluk değeriyle alakalı kazanımların ve bu değerin kazanılma düzeyleri (Özen, Güllaçtı \& Çıkılı, 2002; Aslan, 2007; Aladağ, 2009; Şahan, 2011), sorumluluk eğitimi programının geliştirilmesi veya sorumluluk eğitimiyle alakalı model oluşturma (Dilmaç, 2002; Gündüz, 2014) ve öğretmen görüşlerinin değerlendirilmesi (Yontar, 2007; Sezer, 2008; Tepecik, 2008; Çelik, 2010; Çelikkaya, Filoğlu \& Öktem, 2013) biçiminde ele alındığı gözlenmektedir. Bunun yanında ilköğretim ders kitaplarının değerler eğitimi açısından incelenip sorumluluk değerinin irdelendiği çalışmalar da mevcuttur (Karagöz, 2009; Yaman, Taflan \& Çolak, 2009; Baydar, 2009; Kan, 2010; Gömleksiz \& Cüro, 2010; Aladağ, 2012; Kuş, Merey \& Karatekin, 2013). Öğretim programlarında yer alan kazanımların öğrencilere verilmesinde kullanılan en yaygın ve genel araçlardan biri de hiç şüphesiz ders kitaplarıdır. Son yıllarda yapılan çalışmalar, değerlerin topluma kazandırılmasında ve yaygınlaştırılmasında ders kitaplarının çok etkili olduğunu göstermektedir (Çiçek, Sarışen \& Tüzün, 2009). Ayrıca, alanyazındaki araştırmalar incelendiğinde birçoğunun ilköğretime yönelik yapılan çalışmalar olduğu ortaöğretime yönenlik çalışmalara çok fazla rastlanmadığı görülmektedir. Bu kapsamda yapılan çalışma ile ortaöğretim alanında yapılacak çalışmalara 1şık tutacağı düşünülmektedir. Bir toplumun sağlıklı bir şekilde devamlılığını sağlayan değerler, eğitim yardımıyla aktarılır (Fırat \& Mocan, 2014). Biyoloji dersi de canlıları, yaşamı ve çevreyi konu aldığından, bu değer aktarımında önemli bir görev üstlenmektedir. İstenilen değerlere sahip öğrenciler yetiştirmek için ders kitabı önemli bir eğitim öğretim aracıdır (Ersoy \& Şahin, 2012). Bununla birlikte biyoloji dersinin hedef kitlesi ortaöğretim öğrencileri olup bunlar ergenlik dönemine girmiş öğrencilerdir. Bu öğrencilerde bir kimlik ve davranış kargaşası yaşanabilir (Hökelekli, 2002). Bu karışık evrede onların değer yargılarını oluşturmada biyoloji dersi ve kitapları da önemli bir yere sahiptir (Evin \& Kafadar, 2004; Ersoy ve Şahin, 2012). Dolayısıyla araştırmamızın problem durumunu "biyoloji 11. sınıf ders kitaplarında “sorumluluk" değerine yer verilme durumu nedir?" oluşturmuştur.

\section{Araştırmanın Amacı}

$\mathrm{Bu}$ çalışmanın amacı biyoloji 11. sınıf ders kitaplarında sorumluluk değerine yer verilme durumunun belirlenmesidir.

\section{Yöntem}

\section{Araştırmanın Modeli}

Araştırmada nitel araştırma yöntemlerinden doküman incelemesi kullanılmıştır. Araştırma kapsamında incelenen yazılı belgelerin analiz edilmesiyle veri sağlanmasına doküman incelemesi denilmektedir (Yıldırım \& Şimşek, 2013). Araştırma ile ilgili veriler görüşme ve gözlem yapmaya gerek kalmaksızın belge inceleme yoluyla elde edilebilir. Bu sayede araştırmacı zaman ve kaynak tasarrufu sağlamış olur (Karataş, 2015).

\section{Örneklem}

$\mathrm{Bu}$ çalışmanın veri kaynağını MEB tarafından 2018-2019 eğitim-öğretim yılında ortaöğretim okullarına ücretsiz dağıtılan iki kitaptan biri olan Kök yayıncılığa ait 11. sınıf biyoloji ders kitabı oluşturmaktadır. Bu kitap kolay ulaşılabilir örnekleme yöntemine göre araştırmacıların bulunduğu yere en yakın Erzurum ili Yakutiye ilçesinde bulunan bir ortaöğretim kurumuna dağıtılan ücretsiz kitapdan seçilmiştir. Kitapta toplam 2 ayrı ünite olup ilk ünitenin toplam 7 bölümü ve ikinci ünitenin toplam 2 bölümünün içerisinde yer alan tüm yazılı metinler incelemeye alınmış, bu bölümlerde değinilen sorumluluk değeri tespit edilmiştir. 


\section{Verilerin Çözümlenmesi ve Yorumlanması}

Verilerin analizinde betimsel analiz yapılmıştır. Betimsel analiz, elde edilmiş verilerin daha önceden belirlenmiş temalara göre özetlenmesi ve yorumlanmasını içeren bir nitel veri analizi türüdür. Bu analiz türünde temel amaç, elde edilmiş olan bulguların okuyucuya özetlenmiş ve yorumlanmış bir biçimde sunulmasıdır (Yıldırım \& Şimşek, 2013). Betimsel analiz için kitapta geçen sorumluluk değerinin türleri (bireysel, sosyal ve çevresel sorumluluk) cümle cümle okunarak aranılmıştır. Her bir cümle içindeki, değerlere karşılık gelen sözcükler, belirtilen değerleri açıklayan ifadeler ya da doğrudan veya örtük anlamı veren cümleler alınmıştır. Veri analizinde güvenirliği sağlamak için bu çalışmanın iki araştırmacısı olan alan eğitimcileri tarafindan kitaplar ayrı ayrı incelemişlerdir. Araştırmacılar arasındaki güvenirliği test etmek için; Güvenirlik= (Uzlaşma Sayısı) / (Uzlaşma + Uzlaşmama Sayısı) (Tavşancıl \& Aslan, 2001) formülü kullanılmış ve güvenirliğin \%91 çıktığı görülmüştür. Uzlaşma göstermeyen veriler tartışılarak tekrar gözden geçirilip ortak karara varılmıştır. Analiz süreci yaklaşık 3 hafta sürmüştür.

\section{Bulgular}

Elde edilen bulgular ders kitabındaki ünite ve bölüm sırasına göre sunulmuştur:

11. sınıf ders kitabı iki üniteden oluşup ilk ünite 7 bölüm ikinci ünite 2 bölümden oluşmaktadır. Tablo.1'de bu bölümler içerisinde sorumluluk değerinin dağılımı gösterilmektedir.

Tablo.1. 11. Sınıf biyoloji ders kitabında sorumluluk değerinin dağılımı

\begin{tabular}{|c|c|c|c|}
\hline Üniteler & Bölümler & “Sorumluluk" değerinin geçtiği kısımlar & $\begin{array}{l}\text { Sorumluluk } \\
\text { türü }\end{array}$ \\
\hline & Denetleyici ve & -Sinir sisteminin sağlığı için nelere dikkat etmeliyiz & Bireysel \\
\hline & Düzenleyici & başlıklı kısımda & sorumluluk \\
\hline & Sistem, Duyu & -“Düzenli yaşam ve uyku” okuma metninde & Bireysel \\
\hline & Organları & & sorumluluk \\
\hline & & -“Havuç yemek görme yeteneğimizi artırır mı?” & Bireysel \\
\hline & & Okuma metninde & sorumluluk \\
\hline & & _“Cilt temizliği” okuma metninde & Bireysel \\
\hline & & & sorumluluk \\
\hline & & -“Duyu organlarının sağlığı için nelere dikkat & Bireysel \\
\hline & & etmeliyiz" başlıklı kısımda & sorumluluk \\
\hline & Destek ve & -“Destek ve hareket sisteminin sağlığı için nelere & Bireysel \\
\hline & Hareket & dikkat etmeliyiz" başlıklı kısımda & sorumluluk \\
\hline \multirow{4}{*}{$\begin{array}{l}\text { İnsan } \\
\text { fizyolojisi }\end{array}$} & Sistemi & - “Raşitizm” okuma metninde & Bireysel \\
\hline & & & sorumluluk \\
\hline & Sindirim & -“Sindirim sisteminin sağlığ 1 için nelere dikkat & Bireysel \\
\hline & Sistemi & etmeliyiz başlıklı kısımda & sorumluluk \\
\hline
\end{tabular}




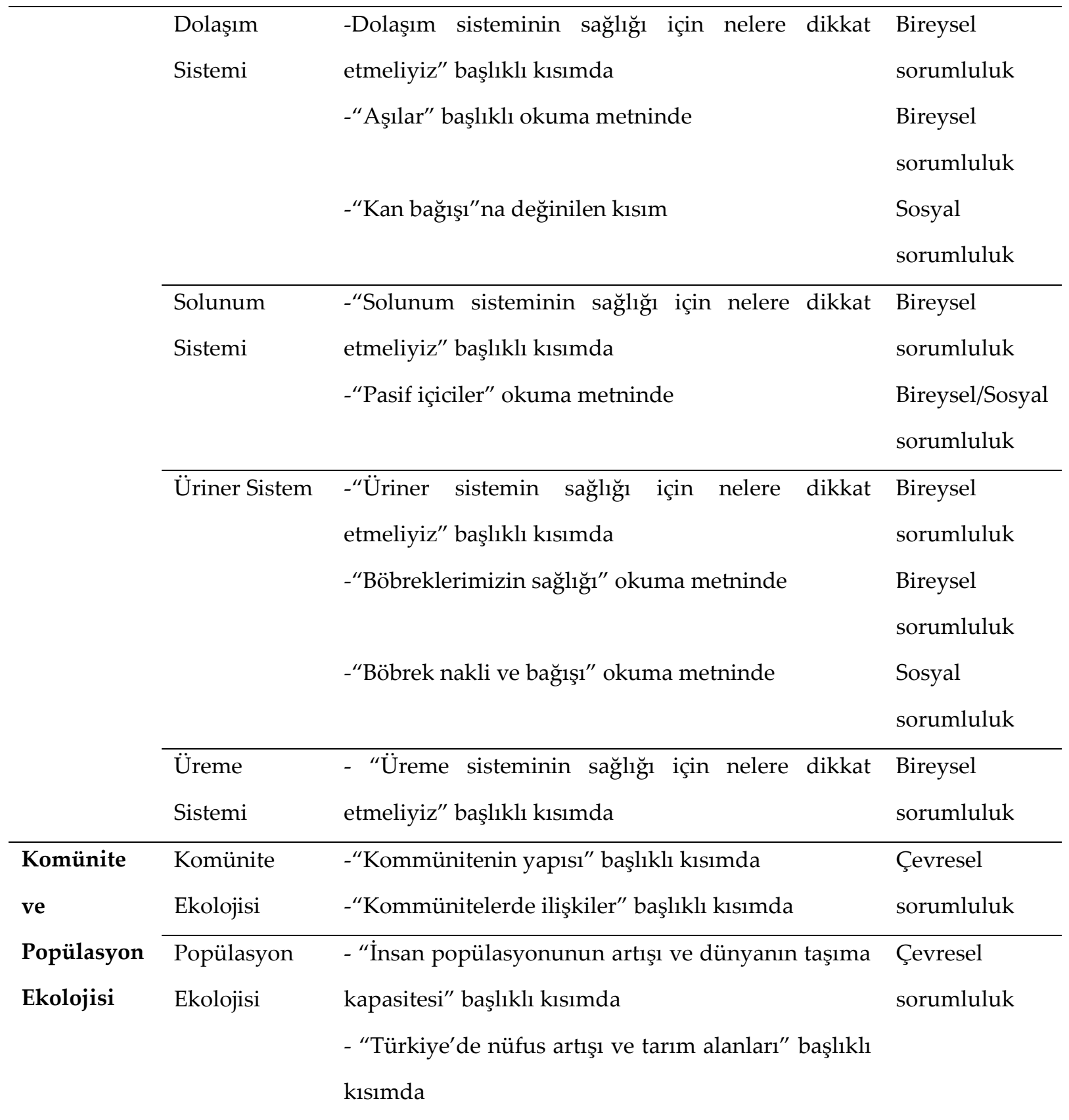

Tablo1' den anlaşıldığı üzere 11. sınıf biyoloji ders kitabında sorumluluk değerine yer verilmekle birlikte en çok bireysel sorumluluk irdelenmiştir. Sosyal ve çevresel sorumluluk ise bireysel sorumluluktan sonra yer almıştır.

“İnsan Fizyolojisi” başl1klı ilk bölümün toplam 7 bölümü olmakla birlikte hepsinde direk sorumluluk değerlerine değinilmemiş olmakla beraber cümle içerisinde belirtilen değerleri açılayan ifadeler ya da doğrudan anlamı veren ifadeler bulunmaktadır. Bu ifadelerin çoğu bireysel sorumluluğun kişinin kendi bedenine yönelik sorumluluğu şeklinde ele alınmaktadır. Üç kısımda ise sosyal sorumluluğa değinilmiştir. Incelenen kitapda sorumluluk değerinin geçtiği kısımlara ayrıntılı bakılırsa: 
“Denetleyici ve Düzenleyici Sistem, Duyu Organları” başlıklı ilk bölümünde

-Sinir sisteminin sağlığı için nelere dikkat etmeliyiz başlıklı kısımda "Beyin sağlığımız için her gün yeterli miktarda su tüketilmesi ve protein içeriği yüksek gıdaların alınması gerektiği de unutulmamalıdır" ve "Yüksek tansiyondan korunmak için özellikle aşırı tuz ve doymuş yağ tüketiminden kaçınılması ve vücut ağırlığının kontrol altında tutulması gerekmektedir” şeklinde bir çok ifade ile bireysel sorumluluğa işaret edilmektedir.

- "Düzenli yaşam ve uyku" okuma metninde "Yeterli uyku uyunmadığında kişinin fiziksel ve ruhsal streslere dayanıklılığı azalır" ve "sağlık ve zindelik için düzenli yaşam ve uyku, vazgeçilmez şartlardır" şeklinde bir çok ifade ile bireysel sorumluluğa işaret edilmektedir.

-“Havuç yemek görme yeteneğimizi artırır mı?” okuma metninde "havuç, herhangi bir görme kusurumuz yoksa içeriğinde bulunan bazı maddeler (örneğin beta karoten) sayesinde göz sağlımızı korumamıza yardımcı olur" cümlesi ile bireysel sorumluluğa vurgu yapılmıştır.

-"Cilt temizliği" okuma metninde "Uygun vücut temizliği birçok sorunu ve hastalığı önler, ortadan kaldırır." cümlesi ile bireysel sorumluluğa vurgu yapılmıştır.

-“Duyu organlarının sağlığı için nelere dikkat etmeliyiz" başlıklı kısımda "Televizyon ve bilgisayara uzun süre ve yakından bakmamalıyız", "Kulaklarımızı temiz tutmalı, sert cisimlerle karıştırmamalıyız." ve "Alkol ve sigara kullanmamalı ve dilimize zarar verebilecek kimyasal maddelerden uzak durmalıyı" şeklinde bir çok öneri ile kişinin kendi bedenine yönelik bireysel sorumluluğuna işaret edilmektedir.

“Destek ve Hareket Sistemi” başl1kl1 2. bölümde

-"Destek ve hareket sisteminin sağlığı için nelere dikkat etmeliyiz" başlıklı kısımda "Destek ve hareket sisteminin sağlığı için dengeli beslenmeye dikkat edilmeli", "yeterince güneş 1şı̆̆ı alınmalı", "iskelet ve kasların gelişmesi ve sağlığı için düzenli olarak yaşa uygun spor yapılmalıdır" gibi ifadelerle bireysel sorumluluk irdelenmiştir.

- "Raşitizm" okuma metninde "Güneş 1şığıından yeterince yararlanmamak, D vitamini ve kalsiyum yönünden zengin besinler almamak, raşitizme yol açabilir” şeklinde bireysel sorumluluğu aktifleştirecek önerilerde bulunulmuştur.

"Sindirim Sistemi” başl1kl1 3. bölümde

-“Sindirim sisteminin sağlı̆̆ kullanılmamalıdır", "Kafeinli ve asitli içeceklerden uzak durulmalıdır” , "Ağız ve diş sağlığına dikkat edilmeli, dişler düzenli olarak firçalanmalıdır” gibi birçok ifade ile bireysel sorumluluk vurgulanmıştır.

“Dolaşım Sistemi” başl1klı 4. bölümde

-Dolaşım sisteminin sağlığı için nelere dikkat etmeliyiz" başlıklı kısımda "Alkol ve sigaradan uzak durulmalıdır", "Çok fazla tuz tüketilmemelidir", "Düzenli spor yapmalı" şeklinde bir çok öneri ile kişinin kendi bedenine yönelik bireysel sorumluluğuna işaret edilmektedir. 
-“Aşılar" başlıklı okuma metninde "Hastalıklardan korunabilmek için temiz su kadar, insan sağlığ açısından önemli olan bir diğer şey ise aşılar ve aşılamadır”, cümlesi ile bireysel sorumluluğa vurgu yapılmıştır.

-"Kan bağışı”na değinilen kısımda “Türk Kızılayı Kan Bağışı Merkezleri'nde kan bağışında"bulunabilirsiniz." , "Kan ve kemik iliği bağışının önemine dikkat çekme amaçlı bir broşür hazırlayınız" şeklinde bilgi ve yönergeler ile direk olmasa da örtük olarak sosyal sorumluluğa değinilmiştir.

\section{“Solunum Sistemi” başlıklı 5. bölümde}

-“Solunum sisteminin sağlığı için nelere dikkat etmeliyiz" başlıklı kısımda "Tütün ve tütün mamulleri gibi solunum sistemine zarar veren maddelerin kullanımından uzak durulmalıdır", "Grip, nezle ve diğer solunum yolu hastalıklarına yakalanan kimselerden uzak durulmalıdır" gibi önerilerle kişinin kendi bedenine yönelik bireysel sorumluluğuna işaret edilmektedir.

-"Pasif içiciler" okuma metninde "Pasif içiciler sigara dumanına maruz kaldıklarında sigara içenlere oranla daha fazla zarar görüyor", "Sigara içen kişilerin yanında bulunan pasif içiciler ise yan akım dumanının zararlarına maruz kalıyor" şeklinde bilgilerle hem sigara içilen ortamdan kendini koruması açısından bireysel sorumluluğa hem de sigara içenlerin çevresindekilere verdiği zarar belirtilerek sosyal sorumluluğa değinilmiştir.

“Üriner Sistem” başl1kl1 6. bölümde

-“Üriner sistemin sağlığı için nelere dikkat etmeliyiz” başlıklı kısımda "Böbrekler ve idrar yolları soğuktan korunmalıdır”, "Aşırı acı ve baharatlı yiyecekler çok fazla tüketilmemelidir” gibi önerilerle bireysel sorumluluğa işaret edilmektedir.

-"Böbreklerimizin sağlığı” okuma metninde böbreklerin hastalanmasa1 durumu ve böbrek yetmeliğinin oluşma nedenleri sıralanarak bireysel sorumluğa vurgu yapılmıştır.

-"Böbrek nakli ve bağışı” okuma metninde "Şu bilinmelidir ki ölen kişinin iki böbreği, karaciğeri, akciğeri, bağırsakları, korneaları ve hatta kemikleri birçok insanın hayatını kurtaracaktır. Bağış yapılmadığındaysa organlar toprağın altında çürüyecektir” şeklinde etkili bir cümle ile sosyal sorumluluğa değinilmiştir.

\section{“Üreme Sistemi” başlıkl1 7. bölümde}

-"Hamileliğin izlenmesinin bebeğin ve annenin sağlığı açısından önemi” başlıklı kısımda "Sigara, alkol ve madde kullanımı, hem anne hem de bebek için çok tehlikeli sonuçlar ortaya çıkarabilmektedir" gibi birçok öneri ile bireysel sorumluğa değinilmiştir.

- "Üreme sisteminin sağlığı için nelere dikkat etmeliyiz” başlıklı kısımda "Cinsel yolla bulaşan hastalıklar hakkında bilgi sahibi olunmalı ve gerekli tedbirler alınmalıdır", "kişisel hijyene dikkat edilmeli, ortak kullanılan tuvaletlerde hijyen kurallarına uygun hareket edilmelidir" şeklinde önerilerle yine bireysel sorumluluğa vurgu yapılmıştır. 
Kommunite ve Populasyon ekolojisi başlıklı 2. ünitenin toplam 2 bölümü olmakla birlikte hepsinde direk sorumluluk değerlerine değinilmemiş olmakla beraber cümle içerisinde belirtilen değerleri açıklayan ifadeler ya da doğrudan anlamı veren ifadelerle çevresel sorumluluğa değinilmiştir. Bunlar:

“Komünite Ekolojisi” başlıklı ilk bölümünde

-“Çevrenizi gözlemlediğinizde, canlıların birbirleri ve çevrelerindeki cansız varlıklarla sürekli etkileşim hâlinde olduğunu fark edersiniz" "Komüniteyi oluşturan canlılar arasında karşılıklı etkileşimler söz konusudur" "Bazen de canlılardan biri bu etkileşimden yarar sağlarken diğeri zarar görebilir veya etkilenmeyebilir" şeklinde ifadelerle canlıların çevresel sorumluluğa örtük olarak değinilmiştir.

“Popülasyon Ekolojisi” başlıklı 2. bölümde ise,

- "İnsan popülasyonunun artışı ve dünyanın taşıma kapasitesi” başlıklı kısımda "İnsan popülasyonu, 20. yüzyıldan itibaren çok hızlı bir şekilde artmaya başlamıştır. Buna bağlı olarak kaynaklar aşırı tüketilmeye başlanmış, çevre sorunları ortaya çıkmış, diğer türler tehlike altına girmiş ve bazı canlıların nesilleri tükenmeye başlamıştır.” şeklinde ki cümle ile "ekolojik ayak izi” kavramına yapılan vurgu ile çevresel sorumluluğa değinilmiştir.

- "Türkiye'de nüfus artışı ve tarım alanları" başlıklı kısımda "Hızlı nüfus artışı, göç ve çarpık kentleşme diğer bazı ülkelerde olduğu gibi Türkiye'de de önemli bir sorun olmuştur.", "Artan nüfusa bağlı olarak ihtiyaçlar karşılanamadığından yurt dışından daha fazla gıda ithalatına gidilmesi gerekebilir. Üretimin artması için ilaç, gübre gibi yapay yollara daha fazla ihtiyaç duyulabileceğinden ürün kalitesi azalabilir, birinci ünitede anlatıldığg gibi etkileri tam olarak bilinmeyen GDO'lu tarım ürünleri daha fazla tüketilmek zorunda kalınabilir." şeklinde ifadelerle yine çevresel sorumluluğa vurgu yapılmıştır.

\section{Tartışma}

Bir toplumun sağlıklı bir şekilde devamlılığını sağlayan değerler, eğitim yardımıyla aktarılır (Fırat \& Mocan, 2014). Biyoloji dersi de canlıları, yaşamı ve çevreyi konu aldığından, bu değer aktarımında önemli bir görev üstlenmektedir. İstenilen değerlere sahip öğrenciler yetiştirmek için ders kitabı önemli bir eğitim öğretim aracıdır (Ersoy \& Şahin, 2012). Dolayısıyla araştırmanın amacına yönelik olarak, 11.sınıf biyoloji ders kitabında yer alan metinler incelenerek sorumluluk değerine yer verilme durumu incelenmiştir. Elde edilen analizler sonucu metinlerde, sorumluluk değeri kitabın 2 ünitesinin içinde bulunan her bölümde tespit edilmiştir. İlk ünite insan fizyolojisi içindeki sistemler bölümleridir. Bu bölümlerde genel olarak insan vücudundaki sistemlerin organ yapıları, işleyişleri, hastalıkları ve korunma yollarına değinilmektedir. Doğal olarak insanın kendi vücut yapısı, karşılaşacağı hastalık ve korunma yollarından bahsedildiğinden kitapta bireysel sorumluluk değerinin vurgulanması beklenmektedir ki "denetleyici ve düzenleyici sistem, duyu organları", "destek ve hareket sistemi", "sindirim sistemi", "dolaşım sistemi", "solunum sistemi", "üriner sistem" ve "üreme sistemi” bölümlerinde bireysel sorumluluk değeri vurgulanmıştır. Ancak bu bölümlerde sadece "ilgili sistemin sağlığı için nelere dikkat etmeliyiz" başlıklı kısım ve sağlık/hastalık ile ilgili okuma metinlerinde bireysel sorumluluk değerine rastlamaktayız. Vücuda ve sağlığa yönelik bireysel sorumluluk, bireyin tercihlerinin kendi sihhati üzerindeki sonuçlarını üstlenmek (mesela, sigara, içki, uyuşturucu kullanımı ile kanser bağlantısını kurabilmek), bedene yönelik kazalardan sakınmak, bilinçsizce davranmanın sorumluluğunu ve sonuçlarını yüklenmek, tercihlerinin sonuçlarını ve tedavi giderlerini yüklenmek şeklinde açıklanmaktadır. Sağlıklı olmada genel geçer kural, her bireyin kendi sağlığından sorumlu olduğudur. Kişisel sorumluluk, bu koşullarda kişinin, kişisel sağlığını korumasıdır (Özen, 2015). Bununla beraber ilgili bölümlerde sosyal sorumluluğa ve çevresel sorumluluğa vurgu yapılmaması bir eksiklik olarak görülebilir. Örneğin bir parfümün vücuda doğrudan sıkılması, cildimize zarar vermesi yanında parfümün 
çevreye/ozon tabakasına zarar vermesi bir çevresel sorumluluktur. Örneği daha da ileri götürsek, bizim için normal gelen bir kokunun başkası için oldukça ağır olması veya çevremizdeki kişilerin parfüm gibi kimyasal madde içeren bazı kokulara alerjik olması da sosyal sorumluluk olarak değerlendirilebilir. Bu nedenle kitaplardaki okuma parçalarında bu tür örneklerin artırılarak her türlü sorumluluk duygusundan öğrencinin haberdar edilmesi önemli görülmektedir.

Bunun dışında "dolaşım sistemi", "solunum sistemi" ve "üriner sistem" de bireysel sorumluluk yanında sosyal sorumluluk değerine de vurgu yapılmıştır. Dolaşım sisteminde kan bağışı, solunum sisteminde pasif içicilik ve üriner sistemde de organ bağışı kısımları ile yaşanılan çevrede birlikte olunan insanlar üzerine düşen görev olarak sosyal sorumluluk değeri irdelenmiştir. Sosyal sorumluluk, paylaşım, işbirliği, başkalarına yardım etmek ve sosyal beceriler olarak tanımlanmaktadır (Scales, Blyth, Berkas \& Kielsmeier, 2000). Yapılan çalışmalar, bireylerin tek başına sağlıklarına özen göstermelerinin yeterli olmadığı kişisel ve sosyal sorumluğun bir dengesinin olması gerektiğini de vurgulamaktadırlar (Özen, 2015).

İkinci ünite Komünite ve Popülasyon Ekolojisini anlatmaktadır. Bu ünitenin bölümlerinde komünitenin ve popülasyonun yapısı, canlıların birlikte yaşamaları ve insan popülasyonunun etkileri anlatılmaktadır. Doğal olarak insan popülasyonunun çevreye etkileri bir sorumluluk değeri taşıdığından genel olarak bu konu içerisinde çevresel sorumluluk değeri vurgulanmaktadır. Çevreye sorumluluk öğrencilere kazandırılması düşünülen değerler arasında yer almaktadır (Komisyon, 2010, s. 20-21). Çevreye karşı sorumluluklarımız sayılamayacak kadar çoktur ama bu sorumlulukların başında temizlik gelir. Doğal zenginlikler ve çevre bizlere birer emanettir. Bunları gerektiği gibi korumak ve zarar verici davranışlardan kaçınmak, ormanlarımızı, bitki örtülerimizi korumak, toprağımızın kimyasal bileşiklerle bozulmasına izin vermemek, nefes aldığımız havanın kirlenmemesi için yakıtlarımızı kaliteli seçmek, havayı kirleten araç ve tesislerin bakımını yaptırmak, canlı türlerinin yok olmaması için uygunsuz avlanmalara izin vermemek de diğer çevresel sorumluluklarımızdır (Ekşi, Türker, Meydan, Şahan, Adıyaman \& Özket, 2010). Bu bulgulara ek olarak ikinci ünitede ulaşılan sonuçlar değerlendirildiğinde genel olarak çevresel sorumluluğun baskın çıkması yukarıda da ifade edilen nedenlerden dolayı ünitenin içeriği açısından beklenen bir durumdur. Ancak çevre ve ekoloji konuları sadece çevresel ve bireysel sorumluluk kapsamında ele alınmamalıdır. Zira çevre ve ekoloji, toplumu da ilgilendiren sosyal bir konudur. Dolayısıyla bu tür konuların yer aldığı ders kitaplarında öğrencilere sosyal sorumluluk duygularını da kazandırabilecek örnek uygulama ve etkinliklere yer verilmesi önemli görülmektedir.

Alan yazında yapılan çalışmalar incelendiğinde biyoloji ders kitaplarındaki değerlerle ilgili bir çalışmaya rastlanmamış olmakla beraber başka alanlarda yapılan araştırmaların mevcut olduğu gözlenmektedir. Öztürk ve Özkan (2018) hayat bilgisi ders kitaplarında sıklıkla sorumluluk değerinin ele alındığı bulgusuna ulaşmışlardır. Güzel Candan ve Ergen (2014, s. 153) tarafından yapılan araştırmada 3. sınıf hayat bilgisi kitabında sevgi ve sorumluluk değerlerine daha fazla yer verilirken Güzel'in (2013) çalışmasında da sorumluluk değeri en fazla yer alan değerlerdendir. Kuş, Merey ve Karatekin (2013, s. 201-202) tarafından yapılan araştırmada 4. ve 5. sınıf sosyal bilgiler ders kitaplarında duyarlılık, vatanseverlik, sorumluluk ve sevgi değerleri daha fazla yer alırken, hayat bilgisi Dersi Öğretim Programı'nda yer alan kazanımları, değerler eğitimi öynünden araştıran Yaşaroğlu'nun (2013) araştırmasında da, en sık "sorumluluk" değerinin işlendiği gözlenmiştir. 5.sınıf matematik ders kitabında en çok yer alan değerler sırasıyla öz denetim, adalet, yardımseverlik ve sorumluluk değeridir (Sayın, Orbay \& Şam, 2019). Şahin ve Başgül, (2019) ortaokul 5, 6, 7 ve 8. matematik ders kitaplarını incelediklerinde sorumluluk değerinin büyük oranda yer aldığını ortaya koymuşlardır. Belet ve Deveci'nin (2008) Türkçe ders kitaplarının değerler açısından incelenmesini hedefleyen araştırmalarında da sorumluluk değeri sıklıkla gözlenmiştir. Bundan dolayı çoğu kitapta bu değerin varlığ değeri pekiştirmelerinin sağlanmak istenmesi ile ilişkilendirilebilir (Candan \& Ergen, 2014). Ortaöğretim ders kitapları üzerine bu konuyla ilgili bir çalışmaya rastlanmamış olduğundan bu çalışmanın sonuçlarıyla kiyaslama yapılamamaktadır. 
Sorumluluk değerinin, biyoloji 11. sınıf ders kitaplarında yer alan değerlerden olması biyoloji dersinin canlı bilimi olarak, doğaya ve canlılara karşı sorumluluk sahibi olmayı sağlayan bir ders (Kiziroğlu, 1988) olmasından kaynaklanabilir. Biyoloji dersi, çevrede rastlanan canlılara, duyarlı olmayı öğretip yardımlaşma kabiliyetlerini geliştirmektedir. Bugünün gençliği, yarının erişkinleri olarak biyolojik sorunlar ve kendi vücudu ile ilgili sağlık meseleleri açısından öğrenci bireysel sorumluluğu yanında, çevreye ve diğer canlılara karşı da önemli bir sorumluluğu olduğunu bu ders ile fark etmektedir. Biyoloji dersi ile öğrencinin doğaya ilgi ve sevgisini uyandırıp öğrenciler daha gençken, doğayı paylaştıkları diğer canlı türlerine karşı sorumlu davranışı öğrenmiş olurlar. Bu açıdan bakılırsa biyoloji dersi diğer canlılara ve fertlere saygılı olmayı amaçlar (Kiziroğlu, 1988).

\section{Sonuçlar ve Öneriler}

Sonuç olarak teknolojinin ve sosyal medyanın toplumu özellikle öğrencileri meşgul ettiği ( Çavuş, Ayhan \& Tuncer, 2016) son yıllarda sorumluluk değerinin öneminin azaldığı (Sezer \& Çoban, 2016) fark edilmektedir. Sorumluluk değerinin kazandırılmasında biyoloji ders kitabında yer alan metinlerin de burada önemli bir rol oynadığını görmekteyiz. Bu yüzden ders kitaplarında yer alan metinler, ögrencilere değer öğretmek için etkili araçlar arasında yer almaktadır. Dolayısıyla ders kitaplarında kullanılan metinlerin öğrencilere değer kazandıracak, onlara doğru davranışları sunacak bir içerikle verilmesi gerekmektedir. Bu noktada özellikle ortaöğretimin diğer kademelerindeki biyoloji ders kitaplarının ve diğer fen alanındaki ders kitaplarının da değerler açısından incelenmesi ve ders kitaplarının değer eğitimindeki etkililiğinin artırılması ile ilgili çalışmaların yapılması önerilebilir. Bu çalışmadaki inceleme sonucuna göre bireysel sorumluluk daha fazla vurgulanırken sosyal sorumluluğa ve çevresel sorumluluğa vurgu yapılmaması bir eksiklik olarak görülebilir. $\mathrm{Bu}$ nedenle kitaplarda her türlü sorumluluk duygusundan öğrencinin haberdar edilmesi önemli görülmektedir. Bireylerin tek başına sağlıklarına özen göstermelerinin yeterli olmadığı bireysel sorumluluk yanında sosyal ve çevresel sorumluğun da bir dengesinin olması gerektiği düşünülmelidir. Ayrıca ders kitaplarında öğrencilere sosyal ve çevresel sorumluluk duygularını kazandırabilecek örnek uygulama ve etkinliklere yer verilmesi de önerilebilir.

\section{Kaynakça}

Acarlı D.S. \& Acarlı H.A. (2018). Ortaöğretim Biyoloji 11 ders kitabı. Kök-e Yayıncılık. Ankara.

Akbaş, O. (2004). Türk milli eğitim sisteminin duyuşsal amaçlarının (değerlerinin) ilköğretim II. kademedeki gerçekleşme derecesinin değerlendirilmesi. Yayınlanmamış Doktora Tezi, Gazi Üniversitesi Eğitim Bilimleri Enstitüsü, Ankara.

Aladă̆, S. (2009). İlköğretim sosyal bilgiler öğretiminde değer ĕgitimi yaklaşımlarının öğrencilerin sorumluluk değerini kazanma düzeyine etkisi. Yayımlanmamış doktora tezi, Gazi Üniversitesi, Eğitim Bilimleri Enstitüsü, Ankara.

Aladağ, S. (2012). İlköğretim sosyal bilgiler öğretiminde değer eğitimi yaklaşımlarının öğrencilerin sorumluluk değerini bilişsel düzeyde kazanmalarına etkisi. Türkiye Sosyal Araştırmalar Dergisi, $161,123-146$.

Aslan, R. (2007). Öğretmen görüşlerine göre ilköğretim birinci basamaktaki ögrencilerin temel bilgi, beceri ve değerler kazanma düzeyleri. Yayınlanmamış yüksek lisans tezi. Anadolu Üniversitesi Eğitim Bilimleri Enstitüsü, Eskişehir.

Baydar, P. (2009). İlköğretim beşinci sınıf sosyal bilgiler programında belirlenen değerlerin kazanım düzeyleri ve bu süreçte yaşa-nılan sorunların değerlendirilmesi. Yayınlanmamış yüksek lisans tezi, Çukurova Üniversitesi Sosyal Bilimler Enstitüsü, Adana. 
Belet, Ş. D. ve Deveci, H. (2008). Türkçe ders kitaplarının değerler bakımından incelenmesi. VII. Ulusal Sınıf Öğretmenliği Sempozyumu. Çanakkale: 2-4 Mayıs 2008.

Berkowitz, L. D. (1963). Responsibility and Dependency, Journal of Abnormal and Social Psychology, $66,429-436$.

Can M. (2013). Zincir Otel Işsletmelerinde Kurumsal Sosyal Sorumluluk Projelerinin Değerlendirilmesi. Afyon Kocatepe Üniversitesi Sosyal Bilimler Enstitüsü, Yüksek Lisans Tezi

Candan, D. G., \& Ergen, G. (2014). 3. sınıf hayat bilgisi ders kitaplarının temel evrensel değerleri içermesi bakımından incelenmesi. Uşak Üniversitesi Sosyal Bilimler Dergisi, 7(1).

Cüceloğlu, D. (1996) İçimizdeki çocuk, İstanbul: Remzi Kitabevi.

Çavuş, S., Ayhan, B., \& Tuncer, M. (2016). Bilgisayar oyunları ve bağımlılık: Üniversite öğrencileri üzerine bir alan araştırması. Iletişsim Kuram ve Araştırma Dergisi 43, 265-289.

Çelik, F. (2010). Beşinci sınıf sosyal bilgiler programında sorumluluk, estetik ve doğal çevreye duyarlılık değerlerinin kazandırılmasına ilişkin öğrenci ve ögretmen görüşleri. Yayımlanmamış yüksek lisans tezi, Anadolu Üniversitesi, Eskişehir.

Çelikkaya, T., Filoğlu, S. \& Öktem, N. (2013). Sosyal bilgiler dersinde değerler eğitimi uygulamalarının öğretmenler tarafından uygulanma düzeyleri, Sosyal Bilgiler Ĕ̆itimi Araştırmaları Dergisi, 4(1), 121-147.

Çiçek, S., Sarışen G. R. \& Tüzün, G. (2009). Ders Kitaplarında İnsan Hakları II Tarama Sonuçları (s. 13-23). İstanbul: Tarih Vakf1 Yayınları.

Dilmaç, B. (2002). İnsanca değerler eğitimi. Nobel Yayın Dağıtım: Ankara.

Ekşi, A., Türker, A. S., Meydan, A., Şahan, R., Adıyaman, K. ve Özket, H. (2010). Fıkıh Ders Kitabı. MEB Yayınları.

Ersoy, T., \& Şahin, F. (2012). Sosyal bilgiler ders kitaplarının değerler eğitimi yaklaşımları açısından incelenmesi. Kuram ve Uygulamada Ĕgitim Bilimleri Dergisi, 12(2), 1535-1558.

Evin, İ. ve Kafadar, O. (2004). İlköğretim sosyal bilgiler programının ve ders kitaplarının ulusal ve evrensel değerler yönünden içerik çözümlemesi. Türk Ĕ̈itim Bilimler Dergisi, 2 (3), 293-304.

Fırat, H., \& Mocan, A. (2014). Türkçe Ders Kitaplarındaki Hikâyelerde Yer Alan Değerler. Türkiye Sosyal Araştırmalar Dergisi, 183(183), 25-49.

Golzar, F.A. (2006). İlköğretim 5. Sinıf Öğrencilerine Yönelik Sorumluluk Ölçĕginin Geliştirilmesi ve Sorumluluk Düzeylerinin Cinsiyet, Denetim Odă̆g ve Akademik Başarlya Göre Incelenmesi. (Yayınlanmamış Yüksek Lisans Tezi). Hacettepe Üniversitesi. Sosyal Bilimler Enstitüsü. Ankara

Gömleksiz, M., \& Cüro, E. (2010). Sosyal bilgiler dersi öğretim programında yer alan değerlere ilişkin öğrenci tutumlarının değerlendirilmesi. Uluslar Arası İnsan Bilimleri Dergisi, 8(1), 95-120.

Gündüz. M. (2014).İlköğretim 3. sinıf hayat bilgisi dersinde sorumluluk değerinin proje tabanlı öğrenme yaklaşımı ile öğretiminin akademik başarı ve tutuma etkisi. Yayımlanmamış doktora tezi, Gazi Üniversitesi Eğitim Bilimleri Enstitüsü, Ankara. 
Güzel, D. (2013). 3. Sınıf Hayat Bilgisi ders kitaplarının evrensel değerleri içermesi bakımından incelenmesi. Yayınlanmamış Yüksek Lisans Tezi. Çanakkale Onsekiz Mart Üniversitesi Eğitim Bilimleri Enstitüsü: Çanakkale.

Hamilton, S. F., \& Fenzel, L. M. (1988). The impact of volunteer experience on adolescent social development: Evidence of program effects. Journal of Adolescent Research, 3(1), 65-80.

Hökelekli, H. (2002). Gençlik ve din : Gençlik, din ve değerler psikolojisi, Ankara: Ankara Okulu Yayınları.

Karagöz, B. (2009). Yapılandırmacı yaklaşıma göre ilköğretim 6. ve 7.sınıf Türkçe ders kitaplarındaki değerlerin incelenmesi. Yayınlanmamış Yüksek Lisans Tezi. Muğla Üniversitesi Sosyal Bilimler Enstitüsü: Muğla.

Karataş, Z. (2015). Sosyal bilimlerde nitel araştirma yöntemleri. Manevi temelli sosyal hizmet araştırmaları dergisi, 1(1), 62-80.

Kiziroğlu, İ. (1988). Günümüzde biyoloji dersi ve amaçları. Hacettepe Üniversitesi Eğitim Fakültesi Dergisi, 3(3).

Komisyon (2010). Imam Hatip Lisesi ve Anadolu Imam Hatip Lisesi Meslek Dersleri Programlart. Ankara: MEB Yayınları.

Kuş Z., Merey, Z., \& Karatekin, K. (2013). İlköğretim 4. ve 5. sınıf Sosyal Bilgiler ders kitaplarında yer alan değerler. Değerler Eğitimi Dergisi, 11(25), 183-214.

Milli Eğitim Bakanlığı [MEB]. (2006). İlköğretim programı. Milli Eğitim Bakanlığı Yayınevi, Ankara.

Özen, Y. (2013). Sorumluluk duygusu ölçeğinin geliştirilmesi; Geçerlik ve güvenirliği. Journal of European Education , 3 (2), 17-23.

Özen Y. (2015). Sorumluluk Eğitimi. Vize yayıncılık, Ankara.

Özen, Y., Güllaçtı, F. \& Çıkılı, Y. (2002). İlköğretim öğrencilerinin sorumluluk duygusu ve davranış düzeyleri ile iç-denetimsel sorumluluk ile dış-denetimsel sorumluluk düzeyleri arasındaki ilişkinin incelenmesi. Erzincan Ë̆itim Fakültesi Dergisi Yayınları, 4(2), 45-58.

Öztürk, T., \& Özkan, Z. S. (2018). Hayat Bilgisi ders kitaplarındaki metin ve görsellerin değerler açısından incelenmesi. Eğitimde Nitel Araştırmalar Dergisi, 6(1), 172-204.

Sayın, V., Orbay, K., \& Şam, E. A. 5. sınıf matematik ders kitabının değerlerimiz açısından incelenmesi. IBAD Sosyal Bilimler Dergisi, 161-171.

Scales, P. C. Blyth, D. A., Berkas, T. H., \& Kielsmeier, J. C. (2000). The effects of service-learning on middle school students' social responsibility and academic success. Journal of Early Adolescence, 20 (3), 332-358.

Sezer, T. (2008). Illköğretim 6. sinıf sosyal bilgiler dersinde sorumluluk değerinin öğretimine ilişkin ögretmen görüşleri. Yayımlanmamış yüksek lisans tezi, Gazi Üniversitesi Sosyal Bilimler Enstitüsü, Ankara.

Sezer, A., \& Çoban, O. (2016). Ortaokul öğrencilerinin sorumluluk değeri algıları. Uşak Üniversitesi Eğitim Araştırmaları Dergisi, 2(1), 22-39. 
Şahan, E. (2011). Illköğretim 5. ve 8. sınıf ders programlarındaki sorumluluk eğitimine dönük kazanımların gerçekleşme düzeyleri. Yayımlanmamış yüksek lisans tezi. Ahi Evran Üniversitesi. Sosyal Bilimler Enstitüsü, Kırşehir.

Şahin, Ö., \& Başgül, M. (2018). Ortaokul matematik ders kitaplarında sosyal değerler. Dicle Üniversitesi Ziya Gokalp Eğitim Fakültesi Dergisi, 34, 91-104

Tavşanc1l, E., \& Aslan, H. (2001). Sözel, yazılı ve diğer materyaller için içerik analizi ve uygulama örnekleri. İstanbul: Epsilon.

Tepecik, B. (2008). Sosyal bilgiler dersinde sorumluluk değerinin kazandırılmasına ilişkin öğretmen görüşleri. Yayımlanmamış yüksek lisans tezi, Anadolu Üniversitesi, Eskişehir.

Tillman, D. (2000). Living values activities for young adults. Deer field Beach-Florida: Health Communications İnc.

Tucker, B.(1999) "Building responsibility." Retrieved on 12/07/ 2007, at URL: http://ag.arizona.edu/pubs/family/az1037.html. 23/07/1999

Yaman, H., Taflan, S., \& Çolak, S. (2009). İlköğretim ikinci kademe Türkçe ders kitaplarında yer alan değerler. Değerler Ĕ̈̆itimi Dergisi, 7(18), 107-120.

Yaşaroğlu, C. (2013). Hayat bilgisi dersi kazanımlarının değerler eğitimi açısından incelenmesi. Turkish Studies, 8 (7), 849-858.

Yavuzer, H. (2000) Çocuk eğitimi el kitabı, İstanbul: Remzi Kitabevi

Yıldırım, A. ve Şimşek, H. (2013). Sosyal Bilimlerde Nitel Araştırma Yöntemleri. Ankara: Seçkin Yayınevi.

Yontar, A. (2007). Sorumluluk ĕgitiminde ceza uygulamalarına ilişkin ilköğretim 5.sınıf öğrenci ve ögretmen görüşlerinin incelenmesi, Yayımlanmamış yüksek lisans tezi, Çukurova Üniversitesi, Sosyal Bilimler Enstitüsü, Adana.

Yontar, A. Yurtal, F. (2006). Sınıf öğretmenlerinin öğrencilerinden bekledikleri sorumluluklar ve sorumluluk kazandırmada kullandıkları yöntemler. Çukurova Üniversitesi Sosyal Bilimler Enstitüsü Dergisi, 15 (2), 411-424. 